\title{
Duality of terrestrial subterranean fauna
}

\author{
Tone Novak ${ }^{1}$, Matjaž Perc, ${ }^{2}$ Saška Lipovšek ${ }^{1,3}$, and Franc Janžekovič ${ }^{1}$
}

\begin{abstract}
:
Novak T., Perc M., Lipovšek S. and Janžekovič F. 2012. Duality of terrestrial subterranean fauna. International Journal of Speleology, 41(2), 181-188. Tampa, FL (USA). ISSN 0392-6672. http://dx.doi.org/10.5038/1827-806X.41.2.5

Terrestrial animals in subterranean habitats are often classified according to their degree of morphological or ecological specialization to the subterranean environment. The commonly held view is that, as distance into a cave increases, the frequency of morphologically specialized, i.e., troglomorphic, species or ecological specialization will increase. We tested this hypothesis for the fauna in 54 caves in Slovenia-the classical land for subterranean biology. We found that there exist two ecologically well separated terrestrial subsurface faunas: one shallow and one deep. 1) The shallow subterranean fauna, adapted to the terrestrial shallow subterranean habitats (SSHs) in the upper $10 \mathrm{~m}$ of subsurface strata, is most diverse. It consists of randomly distributed non-troglobionts and a major group of troglobionts adapted to the soil root zone. 2) The deep subterranean fauna is represented by a minor group of troglobionts, adapted to caves. Troglobionts are strictly divided between the two faunas. There is strong evidence that in karstic ecosystems with deep-rooted vegetation this might be a global pattern, or that in these locations only the shallow subterranean fauna exist.
\end{abstract}

Keywords: endemites; superficial subterranean habitats (SSHs); trogloxenes; troglophiles; troglobionts

Received 10 December 2011; Revised 16 February 2012; Accepted 28 February 2012

\section{INTRODUCTION}

There are two time frames in considering terrestrial subterranean ecology, the classical period of 1832-1980 dealing with caves, and the modern period after the 1980s when a wide range of other subterranean habitats were also considered. After Schmidt (1832) published the first scientific description of an invertebrate well adapted for living in hypogean habitats, the beetle Leptodirus hochenwartii from the cave Postojnska jama in Slovenia, interest in studying subterranean biology and ecology increased enormously. Evidence of eyelessness, depigmentation, relatively long appendages and other convergent characteristics of subterranean animals launched the need for their ecological and morphological classification (Schiödte, 1849, 1851; Schiner, 1854; Racovitza, 1907). Since then, many modifications and refinements have been

${ }^{1}$ Department of Biology, Faculty of Natural Sciences and Mathematics, University of Maribor, Koroška cesta 160, SI-2000-Maribor, Slovenia (tone.novak@uni-mb.si; franc. janzekovic@uni-mb.si)

${ }^{2}$ Department of Physics, Faculty of Natural Sciences and Mathematics, University of Maribor, Koroška cesta 160, SI2000-Maribor, Slovenia (matjaz.perc@uni-mb.si)

${ }^{3}$ Department of Cell Biology, Faculty of Medicine, University of Maribor, Slomškov trg 15, SI-2000-Maribor, Slovenia (sasa. lipovsek@uni-mb.si) suggested (reviewed by Sket, 2008), among which Christiansen's (1962) introduction of the term troglomorphism to denote the typical appearance of welladapted subterranean species has been widely accepted. There are three main ecological groups of animals in habitats beneath the surface (Boutin, 2004; Sket, 2008). 1) Trogloxenes are taxa that enter caves for shelter or feeding opportunities, but which exhibit no morphological adaptation to the hypogean environment and do not complete their life cycle there. 2) Troglophiles (terrestrial) and stygophiles (aquatic animals) alternate between the epigean and hypogean habitats or live permanently in subterranean habitats, and show some moderate adaptation to subterranean conditions, such as reduced eyes and adaptations to compensate for the lack of visual orientation. Some among these do not complete their life cycle underground (subtroglophiles), while others (eutroglophiles) do. 3) Troglobionts and stygobionts complete their life cycle in a completely dark, humid/water and thermally stable hypogean environment. Most of these clearly show troglomorphism. For the purpose of simplification, trogloxenes and troglophiles together are treated here as non-troglobionts.

In caves, according to the classical understanding, trogloxenes have been expected in the entrance zone, troglophiles in the twilight zone, and troglobionts in the totally dark zone, deep inside the cave. In prac- 
tice, ranking among both trogloxenes and troglophiles is often confusing because of the lack of generally accepted criteria for delimiting the two groups or impossible because of the unresolved status of many of these species. Besides, many troglobionts are not consistent with this distributional range and are recorded rarely or sparsely in deep cave sections, but are abundant in terrestrial superficial subterranean habitats (SSHs), like in talus slopes (Juberthie et al., 1980; G. Racovitza, 1983; Juberthie, 2000; Juberthie \& Decu, 1994; Růžička, 1999; Culver \& Pipan, 2009a, b) or, especially in the tropics, near cave entrances (Prous et al., 2004). The terrestrial SSHs are difficult to investigate directly (Růžička \& Klimeš, 2005) and have been much more poorly researched than those in water habitats (Culver \& Pipan, 2009a). They are physically similar to caves within the same area, but with larger annual temperature variation and much more abundant and diverse food supply from the surface and soils. These may be in close contact with caves, and therefore considered a gateway to the deep subterranean habitats (Juberthie \& Decu, 1994; Rưžička, 1999; Culver \& Pipan, 2009a, b; Pipan et al., 2011).

Caves adjacent to other subsurface habitats enable indirect study of these habitats as well. Although caves are much easier to investigate than SSHs, the ecological interpretation of biota in caves is skewed for several reasons. Caves vary considerably in shape, length, altitude and other characteristics, resulting in a wide range of environmentally dissimilar combinations. The usual sampling methods, such as visual inspection, pitfall trapping and Berlese extraction deserve careful interpretation (e.g., Kuštor \& Novak, 1980a; Sabu \& Shiju, 2010; Gotelli \& Collwell, 2011). Most troglobionts are rare in caves, indicating that this is not their preferred habitat (Novak 1989). Some of them show a preference for narrow spaces (e.g., Aphaenops - Juberthie, 1969; Juberthie \& Bouillon, 1983; Speonomus - Delay, 1978; Leptodirus, Anophthalmus - Kuštor \& Novak, 1980a, b), and some have been reported from SSHs (e.g., Tylogonium - Christian, 1987; Eukoenenia - Christian, 2004; Anophthalmus, Aphaenopidius, Orotrechus - Drovenik et al., 2007). Species may vary considerably in abundance from year to year. According to the modern understanding of adaptive processes, a wide range of adaptations and niches can be expected in the subterranean environment, as shown, e.g., among fishes (Riesch et al., 2010; Romero, 2011).

Considering all these facts, the classical understanding of the distribution does not conform to recent knowledge and should be revised on the general level. Here we focus on two points: 1) how the proportion between non-troglobionts and troglobionts changes with distance from the entrance inward and 2) whether the troglobionts represent a unique ecological group or not. We hypothesized that, in territories providing a continuous range of shallow to deep subterranean habitats, such as karst territories, non-troglobionts and troglobionts are evenly distributed within the SSHs. We also hypothesized that there are two ecologically well defined subgroups of troglobionts: 1) species adapted to the SSHs, i.e., the deep soil root zone, and 2) species adapted to caves sensu Culver \& Pipan (2009a). They argue that from the biological/ecological point of view, a "cave" represents a natural space in the solid rock with areas of complete darkness and is larger than a few millimeters in diameter.

\section{MATERIALS AND METHODS}

\section{Terminological notes}

Speleobiological classifications themselves are not the subject of this contribution and do not influence its outcome, but they deserve a brief comment. Most European authors dealing with terrestrial fauna traditionally use "trogloxenes" (see references, e.g., in Juberthie \& Decu, 1994) in place of "subtroglophiles" in the resurrected Pavan-Ruffo classification (Sket, 2008), but not all traditional "troglophiles" rank among "eutroglophiles". To avoid confusion, we pragmatically apply the term "non-troglobionts"-without any intention of introducing a new category-as a group which includes two ecologically different entities: trogloxenes and troglophiles (traditional classification), or subtroglophiles and eutroglophiles (Pavan-Ruffo classification). We understand "troglobionts" in the sense of species confined to subterranean habitats.

\section{Study area and sampling}

In the study area in central and northern Slovenia, using a $10 \times 10 \mathrm{~km}^{2}$ UTM grid, we selected 54 natural caves and artificial galleries (in the following: caves, mapped in Novak, 2005) at altitudes of 260-2450 $\mathrm{m}$ that were morphologically and meteorologically varied for the investigation. As far as possible, these were homogenously scattered within a territory of $7,500 \mathrm{~km}^{2}$ in carbonate and non-carbonate rocks. For the investigation, we chose caves at least $30 \mathrm{~m}$ long, or the longest ones available. The caves were investigated between 1977 and 2001. We sampled in January, April, July and October in a total of 617 sampling sections, every $3.5 \mathrm{~m}$, on average. Besides measuring various environmental parameters, faunal records were provided on two visits within 45-48 hrs by observing cave walls, ceiling and floor, and applying standardized baited pit-fall trapping and Berlese funnels. Such sampling ensured avoiding autocorrelation (cf. Beale et al., 2010) to the highest possible degree. Altogether, 2,468 records were provided, referring to 173,008 individuals of 600 estimated species in total, of which 456 were determined (details in Novak et al., 2004; Novak, 2005).

\section{Statistical Analyses}

In the analysis, presence was used as the most reliable information on biota. We selected ecologically key taxa: the most abundant non-troglobionts, arbitrarily defined as those recorded in $\mathrm{N} \approx \geq 2$ individuals/cave, on average, and all the troglobiotic taxa. Non-troglobionts were unified in the same dataset and troglobionts in the other one. In this way, the non-troglobionts were represented by 19 species and the troglobionts by 15 species-two of them undetermined-plus 4 subspecies. The basic statistical item was the presence of a taxon within a sampling section per season. We observed the frequencies in repetitive presence of the taxon with respect to dis- 
tance from the cave entrance and from the surface, the last referring to the surface vertically above the sampling place within the cave. We first checked the distribution of presence frequencies for normality. The Mann-Whitney $U$ test was used in testing the adequacy of presence frequencies within and between the groups. The spatial distribution of species was evaluated by means of spatial density maps, the density referring to the normalized presence frequencies at any given distance from the entrance or the surface. The normalization was such that for each taxon the sum of densities over the whole distance range was equal to one. The overall similarity between different density maps was compared with the normalized spatial cross-correlation function, $\chi \in[0.1]$ (Kantz \& Schreiber, 2004). The best border between two identified subgroups of the troglobionts was obtained by determination of the smallest relative difference between the cumulative occupancies, $\mathrm{k} \in[0.1]$, where 1 means no, and 0 full separation.

\section{RESULTS}

Within the 54 caves, there were 51,162 individuals of the most abundant non-troglobionts recorded in 2-53 caves, and 3,086 individuals of the troglobiotic taxa in 1-14 caves up to $96 \mathrm{~m}$ from the entrance and $80 \mathrm{~m}$ from the surface (Table 1). Most representatives of the non-troglobionts are Central-European, Alpine, European or more widely distributed species, such as the Holarctic Scoliopteryx libatrix, while Troglohyphantes diabolicus is a local endemite. Among the troglobionts, except for Androniscus stygius, all the others are endemic to an area from a few tens of to a few hundred $\mathrm{km}^{2}$. Only two troglobiotic species: A. stygius and Ceuthmonocharis robici-with two subspecies-were represented by $\geq 2$ individuals/cave, on average, while the others were rare. The spatial density maps of the 19 most abundant non-troglobionts (Fig. 1) and 19 troglobionts (Fig. 2) reveal that the majority of species were most frequently present either about $8 \mathrm{~m}$ equidistant, or $8 \mathrm{~m}$ distant from the entrance and $32 \mathrm{~m}$ from the
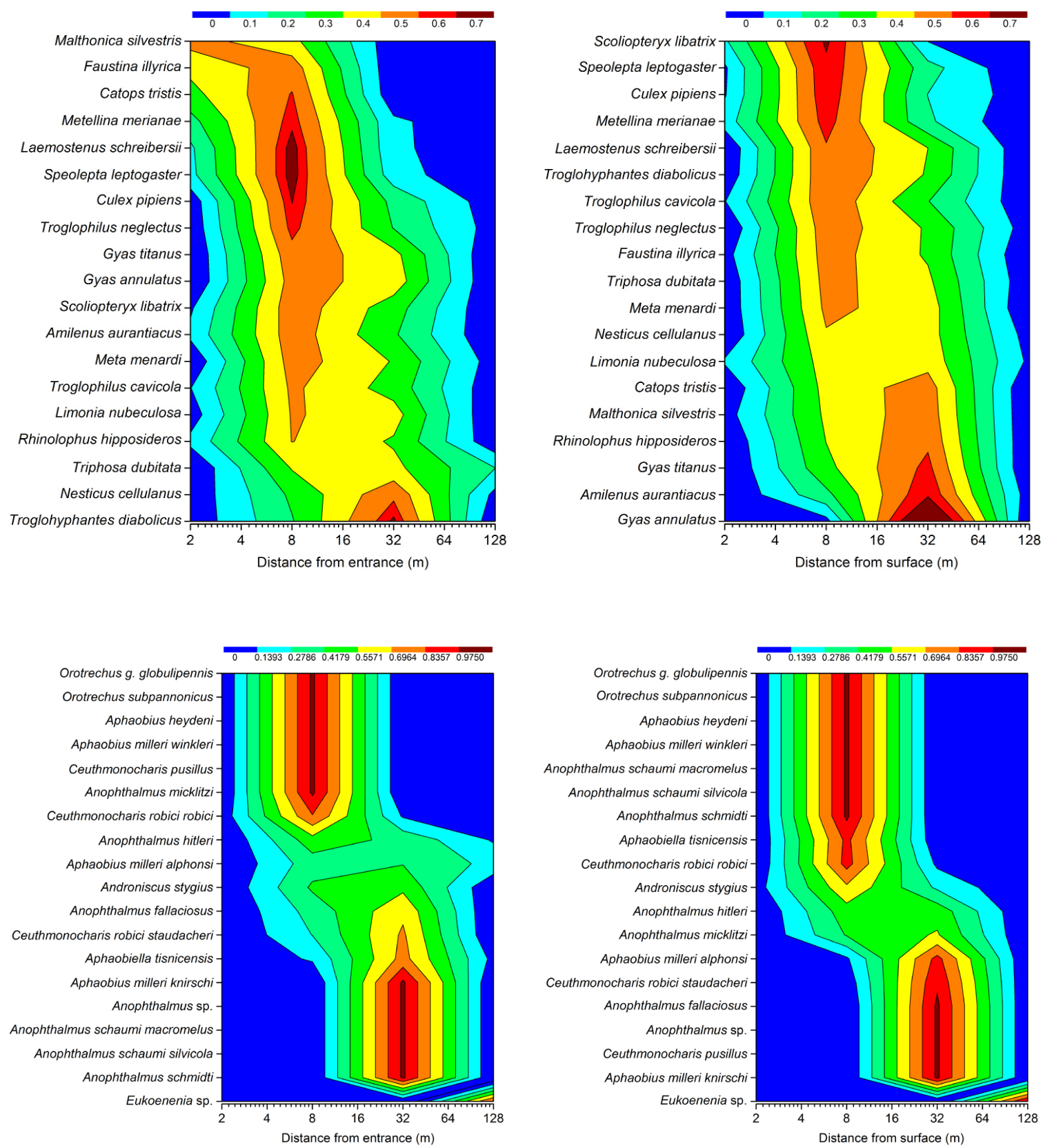

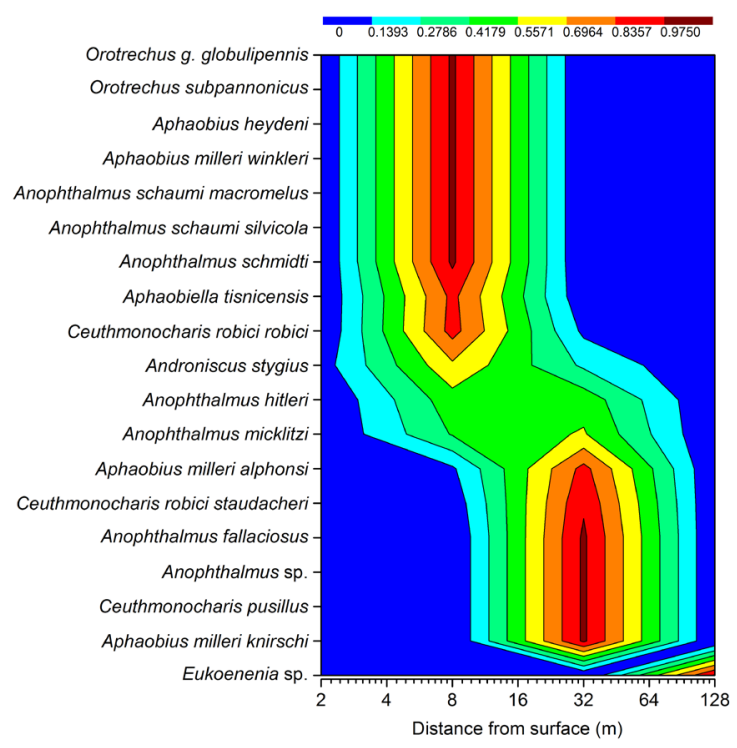

Fig. 2.

Comparative normalized spatial density map of 19 troglobionts in cavities of central and eastern Slovenia. 
Table 1. List of species, their presence and abundance in investigated caves with respect to distance from the entrance and the surface. Traditional European classification (e.g., Juberthie \& Decu, 1994): $x$ trogloxene, $f$ troglophile, b troglobionts, and Pavan-Ruffo classification (Sket, 2008): (s) subtroglophile, (e) eutroglophile.

\begin{tabular}{|c|c|c|c|c|c|c|c|}
\hline $\begin{array}{l}\text { Higher } \\
\text { taxon }\end{array}$ & Family & Species & $\begin{array}{c}\mathrm{N} \text { of } \\
\text { individuals }\end{array}$ & $\begin{array}{c}\mathrm{N} \text { of } \\
\text { inhabited } \\
\text { caves }\end{array}$ & $\begin{array}{c}\mathrm{N} \text { of } \\
\text { presence } \\
\text { observations }\end{array}$ & $\begin{array}{c}\text { Distance } \\
\text { from the } \\
\text { entrance [m] }\end{array}$ & $\begin{array}{l}\text { Distance } \\
\text { from the } \\
\text { surface } \mathrm{m} \text { ] }\end{array}$ \\
\hline Gastropoda & Helicidae & x (s) Faustina illyrica (Stabile, 1864) & 949 & 44 & 247 & $0-28$ & $0-45$ \\
\hline Oniscoidea & Trichoniscidae & b Andronuscus stygius Nemec, 1897 & 104 & 14 & 70 & $2-77$ & $2-80$ \\
\hline \multirow[t]{3}{*}{ Opiliones } & Phalangiidae & x (s) Amilenus aurantiacus (Simon, 1881) & 12,570 & 53 & 701 & $0-77$ & $0-65$ \\
\hline & & $\mathrm{x}$ (s) Gyas annulatus (Olivier, 1791) & 120 & 4 & 14 & $3-55$ & $12-30$ \\
\hline & & x (s) Gyas titanus Simon, 1879 & 139 & 6 & 25 & $4-30$ & $9-37$ \\
\hline \multirow[t]{5}{*}{ Araneae } & Agelenidae & x (s) Malthonica silvestris (L. Koch, 1872) & 180 & 24 & 108 & $0-24$ & $0-27$ \\
\hline & Linyphiidae & f (e) Troglohyphantes diabolicus Deeleman-Reinhold, 1978 & 100 & 15 & 72 & $0-66$ & $2-37$ \\
\hline & Nesticidae & x (s) Nesticus cellulanus (Latreille, 1804) & 282 & 21 & 132 & $0-65$ & $0-65$ \\
\hline & Tetragnathidae & f (e) Meta menardi (Latreille, 1804) & 3,107 & 48 & 555 & $0-69$ & $0-65$ \\
\hline & & x (s) Metellina merianae (Scopoli, 1763) & 883 & 39 & 221 & $0-69$ & $0-65$ \\
\hline Palpigradi & Eukoeneniidae & b Eukoenenia sp. & 2 & 1 & 2 & 100 & 80 \\
\hline \multirow[t]{19}{*}{ Coleoptera } & Carabidae & b Anophthalmus hitleri Scheibel, 1937 & 8 & 1 & 7 & $11-66$ & $8-25$ \\
\hline & & b A. fallaciosus (J. Müller, 1914) & 3 & 2 & 3 & $10-30$ & $18-24$ \\
\hline & & b A. micklitzi (Ganglbauer in G. Müller, 1913) & 7 & 2 & 4 & $9-13$ & $3-16$ \\
\hline & & b A. schaumi macromelus Jeannel, 1926 & 4 & 1 & 3 & $21-29$ & $4-10$ \\
\hline & & b A. s. silvicola Jeannel, 1928 & 1 & 1 & 1 & 41 & 11 \\
\hline & & b A. schmidti Sturm, 1844 & 3 & 1 & 3 & $30-41$ & $9-11$ \\
\hline & & b Anophthalmus sp. & 1 & 1 & 1 & 25 & 32 \\
\hline & & f (e) Laemostenus schreibersii (Küster, 1846) & 328 & 30 & 124 & $0-75$ & $0-80$ \\
\hline & & b Orotrechus g. globulipennis (Schaum, 1860) & 2 & 1 & 1 & 8 & 9 \\
\hline & & b O. subpannonicus Daffner, 1994 & 4 & 1 & 2 & $6-11$ & $8-11$ \\
\hline & Leiodidae & b Aphaobiella tisnicensis Pretner, 1949 & 63 & 4 & 18 & $9-90$ & $7-65$ \\
\hline & & b Aphaobius heydeni Reitter, 1882 & 1 & 1 & 1 & 9 & 13 \\
\hline & & b A. milleri alphonsi G. Müller, 1914 & 17 & 4 & 10 & $10-77$ & $9-46$ \\
\hline & & b A. m. knirschi G. Müller, 1913 & 34 & 1 & 8 & $20-55$ & $34-54$ \\
\hline & & b A. m. winkleri Mandl, 1944 & 2 & 2 & 2 & $3-12$ & $5-10$ \\
\hline & & x (s) Catops tristis (Panzer, 1794) & 106 & 12 & 28 & $0-15$ & $2-43$ \\
\hline & & b Ceuthmonocharis pusillus Jeannel, 1924 & 64 & 1 & 79 & $0-42$ & $0-29$ \\
\hline & & b C. robici robici Ganglbauer, 1899 & 2,579 & 4 & 19 & $5-33$ & $13-25$ \\
\hline & & b C. r. staudacheri Müller, 1919 & 188 & 1 & 9 & $6-13$ & $24-26$ \\
\hline \multirow[t]{3}{*}{ Diptera } & Culicidae & x (s) Culex pipiens (Linnaeus, 1758) & 5,373 & 50 & 441 & $0-96$ & $0-80$ \\
\hline & Limoniidae & x (s) Limonia nubeculosa Meigen, 1804 & 3,544 & 50 & 315 & $0-84$ & $0-65$ \\
\hline & & f (e) Speolepta leptogaster (Winnertz, 1863) & 575 & 31 & 235 & $0-68$ & $0-64$ \\
\hline \multirow[t]{2}{*}{ Lepidoptera } & Geometridae & x (s) Triphosa dubitata (Linnaeus, 1758) & 539 & 32 & 187 & $0-75$ & $2-65$ \\
\hline & Noctuidae & x (s) Scoliopteryx libatrix (Linnaeus, 1758) & 836 & 50 & 265 & $0-84$ & $2-65$ \\
\hline \multirow[t]{2}{*}{ Orthoptera } & Rhaphidophoridae & f (s) Troglophilus cavicola (Kollar, 1833) & 15,730 & 48 & 1565 & $0-92$ & $0-67$ \\
\hline & & f(s) Troglophilus neglectus Krauss, 1879 & 5,673 & 44 & 1203 & $0-88$ & $0-65$ \\
\hline Mammalia & Rhinolophidae & x (s) Rhinolophus hipposideros (Bechstein, 1800) & 128 & 39 & 95 & $1-84$ & $2-65$ \\
\hline
\end{tabular}

surface or vice versa, while only six of them were $32 \mathrm{~m}$, or deeper inside, equidistant from both (Tables 1,2$)$. With respect to distance from the entrance and from the surface, there were no statistical differences in any taxon (Mann-Whitney, 0.069 $>$ p $>0.953$ for the non-troglobiont, and $0.754>p>0.981$ for the troglobionts) or within any group (Mann-Whitney, $\mathrm{p}=0.454$ for the whole non-troglobiont group, and $\mathrm{p}=0.427$ for the troglobiont group). This indicates that each species and each group as a whole inhabited hypogean habitats proportionally distant from the epigean en- vironment, irrespective of the way of measuring the distance. The correlations between the density maps were nearly perfect within each group (entrance vs. surface, the non-troglobiont group, $r=0.951$; the troglobiont group, $r=0.972$ ), and high between the two groups (entrance vs. entrance, $r=0.721$; surface vs. surface, $r=0.770)$. The troglobiont group was bimodal with two clearly separated subgroups (Fig. 2), and such a trend is also evident in non-troglobionts (Fig. 1 ). There was a highly significant difference in distribution between the non-troglobionts vs. the troglo- 
Table 2. Species ranked according to frequency of presence in the 54 cavities with respect to distance from the entrance and the surface. Traditional European classification: $x$ trogloxene, $f$ troglophile, $b$ troglobiont, and Pavan-Ruffo classification: (s) subtroglophile, (e) eutroglophile. Troglobionts adapted to the deep subterranean environment in grey.

\begin{tabular}{|c|c|c|c|c|}
\hline $\begin{array}{l}\text { Distance } \\
\text { from the } \\
\text { entrance }[\mathrm{m}]\end{array}$ & Distance from the surface $[\mathrm{m}]$ & & & \\
\hline & 8 & 16 & 32 & 80 \\
\hline 4 & $\mathrm{x}$ (s) Malthonica silvestris & & & \\
\hline 8 & $\begin{array}{l}\text { x (s) Faustina illyrica } \\
\text { f (e) Meta menardi } \\
\text { x (e) Metellina merianae } \\
\text { x (e) Nesticus cellulanus } \\
\text { b Anophthalmus hitleri } \\
\text { f (e) Laemostenus schreibersii } \\
\text { b Aphaobius heydeni } \\
\text { b A. milleri winkleri } \\
\text { b Ceuthmonocharis robici robici } \\
\text { b Orotrechus g. globulipennis } \\
\text { b O. subpannonicus } \\
\text { x (s) Culex pipiens } \\
\text { f (e) Speolepta leptogaster } \\
\text { x (s) Scoliopteryx libatrix } \\
\text { x (s) Troglophilus cavicola } \\
\text { x (s) T. neglectus } \\
\text { x (s) Rhinolophus hipposideros }\end{array}$ & x (s) Limonia nubeculosa & $\begin{array}{l}\text { x (s) Amilenus aurantiacus } \\
\text { x (s) Gyas annulatus } \\
\text { x (s) G. titanus } \\
\text { b Anophthalmus micklitzi } \\
\text { x (s) Catops tristis } \\
\text { b Ceuthmonocharis pusillus }\end{array}$ & \\
\hline 16 & x (s) Triphosa dubitata & & & \\
\hline 32 & $\begin{array}{l}\text { b Andronuscus stygius } \\
\text { f (e) Troglohyphantes diabolicus } \\
\text { b Anophthalmus schaumi macromelus } \\
\text { b A. schaumi silvicola } \\
\text { b A. schmidti } \\
\text { b Aphaobiella tisnicensis }\end{array}$ & & $\begin{array}{l}\text { b Anophthalmus fallaciosus } \\
\text { b Anophthalmus sp. } \\
\text { b Aphaobius milleri alphonsi } \\
\text { b A. milleri knirschi } \\
\text { b Ceuthmonocharis robici staudacheri }\end{array}$ & \\
\hline 100 & & & & b Eukoenenia sp. \\
\hline
\end{tabular}

biont group with respect to distance from both the entrance and the surface (Mann-Whitney, $\mathrm{p}<0.001$ ), caused by a bimodal presence of troglobionts. In the maps, the $8 \mathrm{~m}$ and $32 \mathrm{~m}$ groups represent the most distinctive regions, yielding $\mathrm{K} \approx 10^{-6}$ and indicating nearly-perfect justification of grouping.

\section{DISCUSSION}

The karst in Slovenia is the classical landscape for subterranean biology, often called the cradle of speleobiology. The caves under investigation together with adjacent epikarst, talus slopes and other SSHs form a more or less interconnected frame of subsurface habitats at the disposal of subsurface animals. For troglobionts that are rare in caves, cumulative frequencies of presence help to detect places where their preferred habitats inaccessible to humans are in contact with a cave. These data are even more limited than their low abundance data, rendering impossible the use of most standard statistical methods. Spatial density maps are applicable to abundant data, like studying a species or community dynamics (e.g., Novak et al., $2010 b)$, as well as to such limited datasets.

With respect to their activity in the subterranean environment, the recorded non-troglobionts represent a network of species, showing a range of habitat adaptations, rather than two ecologically clearly separated groups. Most of them belong to the parietal associa- tion, i.e., animals sojourning especially on the cave walls and ceiling near entrances. Except in a few cases (e.g., Novak et al., 2010a), these assemblages differ in composition and functioning to a limited extent from France to Romania. While these are only exceptionally endemic, troglobionts are highly endemic as reported for many stygobionts and other troglobionts (Gibert \& Deharveng, 2002; Christman et al., 2005; Culver \& Pipan, 2009a; Reboleira et al., 2011). In this way, a number of widely distributed and locally endemic SSH species co-occur by chance; no characteristic ecological community can be recognized (cf. Ricklefs, 2008). While non-troglobiotic taxa have been ecologically relatively well investigated (Supplement 1 ), the troglobionts have in principle not been studied or have been understudied.

Many SSH species are dependant on roots (Juberthie et al., 1980; Ashmole, 1994). Rich troglobiotic fauna has been reported from shallow lava tubes (e.g., Medina \& Oromi, 1990; Oromi et al., 1990; Howarth, 2004; Howarth et al., 2007) and from shallow Brazilian caves, especially ferrugineous ones (Souza-Silva et al., 2011), all of them with extensive tree root systems protruding into the caves and directly or indirectly supporting the cave fauna. The lava and iron ore rocks provide an extensive SSH system of micro- and mesovoids, probably allowing migration of the fauna into macro-caves (Souza-Silva et al., 2011). In the temper- 
ate biome, trees grow relatively shallow roots, maximally 4.4-6.3 m deep (Canadell et al., 1996). This is why in the caves from our investigation they rarely grow through the ceiling. Besides, larger fissures and similar habitats connecting caves and adjacent SSHs are mostly as unstable as the cave entrance zone, representing an ecotone between the epigean and hypogean environments (Prous et al., 2004; Culver, 2005). This is true at least with respect to the air flow, causing troglobionts to avoid such habitats. Consequently, these habitats contribute only occasional SSH individuals to cave biota by hazard. In spite of that, the much larger number of troglobiotic taxa in the shallow peak of their bimodal distribution indicates that the SSH species are the most diverse group of troglobionts. This demonstrates the crucial importance of research into this group, adapted to the deep root zone, i.e., the rhizosphere (Cardon \& Whitbeck, 2007), for progress in understanding the ecology of the subterranean environment as well as of ecosystems providing the deep rhizosphere. Deep subterranean troglobionts are much less diverse. Among them, at least a few inhabit the terrestrial phreatic environment - "milieu phreatique terrestre" sensu Jeannel (1926), i.e., habitats consisting of tiny water trickles in channels originating in the epikarst and passing into the deep karstic massifs. Such a case is the bathysciin beetle Aphaobiella tisnicensis, occurring in mass (more than 1000 individuals per $\mathrm{m}^{2}$ ) in the hardly accessible cave Štravsova luknja near Velenje (not among the 54 investigated caves) on slowly percolated sandy ground (own unpublished data).

Our finding that most non-troglobionts and troglobionts are primarily distributed and coexist within the upper $10 \mathrm{~m}$ of subsurface strata is, in addition, congruent with the following facts. The belowground communities are usually much more diverse than the corresponding aboveground ones (Wardle, 2006); multiple independent colonization of the subterranean habitat is common in cave-adapted species (Porter, 2007) and in terrestrial species most probably via the SSHs (Růžička, 1999; Culver \& Pipan, 2009b); moreover, species diversity generally declines from the shallow towards the deep subterranean habitats (Culver \& Pipan, 2009a). To most non-troglobionts, the entrance cave zone represents either a preferable habitat or merely a conduit from the epigean habitat to deeper habitats where a daily rest or seasonal inactive hypogean ecophase can unfold and vice versa. To the other non-troglobionts and all troglobionts, the entrance cave zone acts as a disturbance, disrupting, or limiting their preferred subsurface habitat within the range from SSHs to deep caves.

In conclusion, the terrestrial fauna in the classical European subterranean environment consists of two well separated faunas: The SSH fauna is represented by non-troglobionts and a major group of troglobionts, while the deep subterranean fauna consists of a minor group of troglobionts. Thus, troglobionts are strictly divided into the two identified ecological subgroups. Consequently, non-troglobionts as well as troglobionts are most diverse and randomly distributed in the upper $10 \mathrm{~m}$ of subsurface strata corresponding to the cave entrance zone and the SSHs. Wherever in the world troglobionts occur in vegetation landscapes, they most likely inhabit the soil root zone, and, if also present in deep subterranean habitats, they can be expected to be much more diverse in the SSHs.

\section{ACKNOWLEDGEMENTS}

We are indebted to David C. Culver for insightful discussion and suggestions during the preparation of the manuscript, and to Tanja Pipan and two anonymous referees for further suggestions for improvement. Michelle Gadpaille valuably improved the language. This study was partly supported by the Slovene Ministry of Higher Education, Science and Technology within the research program Biodiversity (grant P1-0078), and by the Slovenian Research Agency (grant Z1-2032).

\section{REFERENCES}

Ashmole N.P., 1994 - Colonization of the underground environment in volcanic islands. Mémoires de Biospéologie, 20: 1-11.

Beale C.M., Lennon J.J., Yearsley J.M., Brewer M.J. \& Elston D.A., 2010 - Regression analysis of spatial data. Ecology Letters, 13: 246-264. http://dx.doi.org/10.1111/j.1461-0248.2009.01422.x

Boutin C., 2004 - Organisms: classification. In: Gunn J. (Ed)., Encyclopedia of Cave and Karst Science. New York and London: Fitzroy Dearborn : 548-549.

Canadell J., Jackson R.B., Ehleringer J.R., Mooney H.A., Sela O.E. \& Schulze E.-D., 1996 - Maximum rooting depth of vegetation types at the global scale. Oecologia, 108: 583-595. http://dx.doi.org/10.1007/BF00329030

Cardon Z.G. \& Whitbeck J.L., 2007 - The Rhizosphere: An Ecological Perspective. Elsevier Academic Press, Boston, 232 p.

Christian E., 1987 - Composition and origin of underground arthropod fauna in an extrazonal permafrost soil of central Europe. Biology and Fertility of Soils, 3: 27-30. http:/ /dx.doi.org/10.1007/BF00260575

Christian E., 2004 - Palpigraden (Tastenläufer). Spinnentiere in einer Welt ohne Licht. In: Thaler K. (Ed)., Diversität und Biologie von Webspinnen, Skorpionen und anderen Spinnentieren. Denisia, 12: 473-483.

Christiansen K., 1962 - Proposition pour la classification des animaux cavernicoles. Spelunca, 2: 75-78.

Christman M.C., Culver D.C., Madden M. \& White D., 2005 - Patterns of endemism of the eastern North American cave fauna. Journal of Biogeography, 32: 1441-1452. http://dx.doi.org/10.1111/j.1365-2699.2005.01263.x

Culver D.C., 2005 - Ecotones. In: Culver D.C. \& White W.B. (Eds)., Encyclopedia of Caves. Amsterdam: Elsevier: 206-208.

Culver D.C. \& Pipan T., 2009a - The Biology of Caves and Other Subterranean Habitats. Oxford University Press, Oxford, New York, 256 p.

Culver D.C. \& Pipan, T., 2009b - Superficial subterranean habitats - gateway to the subterranean realm? Cave and Karst Science, 35: 5-12.

Delay B., 1978 - Milieu souterrain et la écophysiologie de la reproduction et du développement des Coléoptères Bathysciinae. Mémoires de Biospéologie, 5, 1-349. 
Drovenik B., Weber F., Paill W. \& Assmann T., 2007 - Aphaenopidius kamnikensis Drovenik, 1987 in Kärnten. Angewandte Carabidologie, 8: 73-76.

Gibert J. \& Deharveng L., 2002 - Subterranean ecosystems: a truncated functional biodiversity. Bioscience, 52: 473-481.

http://dx.doi.org/10.1641/0006-3568(2002) 052[0473:SEATFB]2.0.CO;2

Gotelli N.J. \& Collwell R.K., 2011 - Quantifying biodiversity: procedures and pitfalls in the measurement and comparison of species richness. Ecology Letters, 4: 379-391.

http://dx.doi.org/10.1046/j.1461-0248.2001.00230.x

Howarth F.G., 2004 - Hawaiian Islands: biospeleol ogy. In: Gunn J. (Ed)., Encyclopedia of Cave and Karst Science. New York and London: Fitzroy Dearborn: 863-867.

Howarth F.G., James S.A., McDowell W., Preston D.J. \& Imada C.T., 2007 - Identification of roots in lava tube caves using molecular techniques: implications for conservation of cave arthropod faunas. Journal of Insect Conservation, 3: 251-261. http://dx.doi.org/10.1007/s 10841-006-9040-y

Jeannel R., 1926 - Faune cavernicole de la France. Lechevalier, Paris, 334 p.

Juberthie C., 1969 - Relation entre le climat, le microclimat et Aphaenops cerberus dans la grotte de Saint-Catherine (Ariége). Annales de Spéléologie, 24: 75-104.

Juberthie C., 2000 - The diversity of the karstic and pseudokarstic hypogean habitats in the world. In: Wilkens H., Culver D.C. \& Humphreys W.F. (Eds)., Subterranean Ecosystems. Amsterdam: Elsevier: 17-39.

Juberthie C. \& Bouillon M., 1983 - Présence des Aphaenops (Coléoptères Trechinae) dans le Milieu Souterrain Superficiel des Pyrénées. Mémoires de Biospéologie, 10: 91-98.

Juberthie C. \& Decu V., 1994 - Structure et diversité du domain souterrain; particularités des habitats et adaptations des espèces. In: Juberthie C. \& Decu V. (Eds)., Encyclopaedia Biospeologica. Tome 1. Moulis and Bucharest: Société de Biospéologie: $5-22$.

Juberthie C., Delay B. \& Bouillon M., 1980 - Sur l'existence du milieu souterrain superficiel en zone non calcaire. Comptes Rendus de l'Académie des Sciences de la France D, 290: 49-52.

Kantz H. \& Schreiber T., 2004 - Nonlinear Time Series Analysis. Cambridge University Press, Cambridge, $376 \mathrm{p}$.

Kuštor V. \& Novak T., 1980a - Individual differences in trapping activity of two underground beetle species. Mémoires de Biospéologie, 7: 77-84.

Kuštor V. \& Novak T., 1980b - Some factors influencing the efficiency of trapping two underground beetle species. Zoologische Anzeiger, 205: 323-332.

Medina A.L. \& Oromi P., 1990 - First data on the superficial underground compartment on La Gomera (Canary Islands). Mémoires de Biospéologie, 17: 87-91.

Novak T., 1989 - Ecological evaluation of some organisms for the hypogean cenoses. (In Slovene). PhD Dissertation, University of Ljubljana, Slovenia: $111 \mathrm{p}$.
Novak T., 2005 - Terrestrial fauna from cavities in Northern and Central Slovenia, and a review of systematically ecologically investigated cavities. Acta Carsologica, 34: 169-210.

Novak T., Lipovšek Delakorda S., Senčič L., Pabst M.A. \& Janžekovič F., 2004 - Adaptations in phalangiid harvestmen Gyas annulatus and $\mathrm{G}$. titanus to their preferred water current adjacent habitats. Acta Oecologica, 26: 45-53.

http://dx.doi.org/10.1016/j.actao.2004.03.004

Novak T., Thirion C. \& Janžekovič F., 2010a - Hypogean ecophase of three hymenopteran species in Central European caves. Italian Journal of Zoology, 77: 469-475.

http://dx.doi.org/10.1080/11250000903451809

Novak T., Tkavc T., Kuntner M., Arnett A.E. Lipovšek Delakorda S., Perc M. \& Janžekovič F., 2010b Niche partitioning in orbweaving spiders Meta menardi and Metellina merianae (Tetragnathidae). Acta Oecologica, 36: 522-529. http://dx.doi.org/10.1016/j.actao.2010.07.005

Oromí P., Martín J.L., Ashmole N.P. \& Ashmole M.J., 1990 - A preliminary report on the cavernicolous fauna of the Azores. Mémoires de Biospéologie, 17: 97-105.

Pipan T., López H., Oromí P., Polak S. \& Culver D.C., 2011 - Temperature variation and the presence of troglobionts in terrestrial shallow subterranean habitats. Journal of Natural History, 45: 253-273. http:/ /dx.doi.org/10.1080/00222933.2010.523797

Porter M.L., 2007 - Subterranean biogeography: what have we learned from molecular techniques? Journal of Cave and Karst Studies, 69: 179-186.

Prous, X., Ferreira, R.L. \& Martins R.P., 2004 - Ecotone delimitation: Epigean-hypogean transition in cave ecosystems. Austral Ecology, 29: 374-382. http://dx.doi.org/10.1111/j.1442-9993.2004.01373.x

Racovitza E.G., 1907 - Essai sur les problemes biospéologiques. Archives de Zoologie Expérimentale et Générale (Biospéol. I), 4e ser., 6: 371-488.

Racovitza G., 1983 - Sur les relations dynamiques entre le milieu souterrain superficiel et milieu cavernicole. Mémoires de Biospéologie, 10: 85-89.

Reboleira A.S.P.S., Borges P.A.V., Gonçalves F., Serrano A.R.M. \& Oromí P., 2011 - The subterranean fauna of a biodiversity hotspot region - Portugal: an overview and its conservation. International Journal of Speleology, 40: 23-37.

http://dx.doi.org/10.5038/1827-806X.40.1.4

Ricklefs R., 2008 - Disintegration of the ecological community. American Naturalist, 172: 741-750. http://dx.doi.org/10.1086/593002

Riesch R., Plath M. \& Schlupp I., 2010 - Toxic hydrogen sulfide and dark caves: life-history adaptations in a livebearing fish (Poecilia mexicana, Poeciliidae). Ecology, 91: 1494-1505.

http://dx.doi.org/10.1890/09-1008.1

Romero A., 2011 - The evolution of cave life. American Scientist, 99: 144-151. http://dx.doi.org/10.1511/2011.89.144

Růžička V., 1999 - The first steps in subterranean evolution of spiders (Araneae) in Central Europe. Journal of Natural History, 33: 255-265. http://dx.doi.org/10.1080/002229399300407 
Růžička V. \& Klimeš L., 2005 - Spider (Araneae) communities of scree slopes in the Czech Republic. Journal of Arachnology, 33: 280-289. http://dx.doi.org/10.1636/04-44.1

Sabu T.K. \& Shiju R.T., 2010 - Efficacy of pitfall trapping, Winkler and Berlese extraction methods for measuring ground-dwelling arthropods in moist-deciduous forests in the western Ghats. Journal of Insect Science, 10: 98, 1-17. http://dx.doi.org/10.1673/031.010.9801

Schiner J.R., 1854 - Fauna der Adelsberger-, Lueger-, und Magdalenen Grotte. In: A. Schmidl (Ed).. Zur Höhlenkunde des Karstes. Die Grotten und Höhlen von Adelsberg, Lueg, Planina und Laas. Wien: Braumüller: 231-272.

Schmidt F., 1832 - Beitrag zu Krain's Fauna. Illyrisches Blatt, $21^{\text {st }}$ Jan 1832, Laibach (= Ljubljana), 3: 9-10.

Schiödte J.C., 1849 - Specimen faunae subterraneae. Bidrag til den underjördiske Fauna. Transactions of the Royal Danish Society of Sciences, $5^{\text {th }}$ ser., Div. Nat.-hist. Math., 2: 1-39.
Schiödte J.C., 1851 - Specimen faunae subterraneae. Transactions of the Royal Entomological Society of London, 6: 134-157.

Sket B., 2008 - Can we agree on an ecological classification of subterranean animals? Journal of Natural History, 42: 1549-1563. http://dx.doi.org/10.1080/00222930801995762

Souza-Silva M., Martins R.P. \& Ferreira R.L., 2011 - Cave lithology determining the structure of the invertebrate communities in the Brazilian Atlantic Rain Forest. Biodiversity and Conservation, 20: 1713-1729. http://dx.doi.org/10.1007/s10531-011-0057-5

Wardle D.A., 2006 - The influence of biotic interactions on soil biodiversity. Ecology Letters, 9: 870-886. http://dx.doi.org/10.1111/j.1461-0248.2006.00931.x

Supplement 1. Publications, additional to the general references, providing ecological information on the most abundant non-troglobionts in central Europe. - Available on request from the authors. 